\title{
Local Tax Reforms and Intergovernmental Fiscal Transfers Policy: The Relevance of Governance Forum
}

\author{
Paul Onyango-Delewa ${ }^{1}$
}

\section{ARTICLE INFO}

Submitted : 21.07.2020

Revised : 09.10.2020

Accepted : 11.11.2020

Available : 29.12 .2020

iThenticate similarity score: $8 \%$

JEL classification:

$\mathrm{H} 29, \mathrm{H} 71, \mathrm{H} 77$

Keywords:

Local Government, Local Tax Reforms, Governance Forum, Fiscal Transfers Policy

\begin{abstract}
A B S T R A C T
This study invokes fiscal federalism literature by examining tax reformsintergovernmental fiscal transfers policy relationship in local government. Additionally, it investigates whether a governance forum mediates that association. Data from eight districts, two municipalities, and 80 subcounties in Uganda's North-Western region were tested employing structural equation modeling. For quite a long time, Uganda, an East African country, has been acclaimed for its federalism proficiency. Findings indicate that: much as tax autonomy, coordination capacity, tax inconsistency, and corruption; notable tax reforms attributes, predict transfers policy changes, governance forum plays no mediation role in the tax reforms-transfers policy set-up. Implications for theory-researchpractice triangulation are discussed, and future research direction has also been proposed.
\end{abstract}

Cite this article as: Onyango-Delewa, P. (2020). "Local Tax Reforms and Intergovernmental Fiscal Transfers Policy: The Relevance of Governance Forum", International Journal of Public Finance, 5(2), 253-272.

\section{Introduction}

The conventional understanding of fiscal federalism practice, theory, and research is that inter-governmental fiscal transfers (IGFTs) constitute the main funding source for sub-national entities. This situation obtains in the majority fiscallydecentralized countries of both the developed and developing world (Breton \& Scott, 1978; de Mello, 1999; Shankar \& Shah, 2003). The most dominant type of fiscal

\footnotetext{
${ }^{1}$ Senior Lecturer, Gulu University, Faculty of Business and Development, Uganda, ORCID: 0000-00027770-6744, ponydel2005@gmail.com
} 
transfers, especially in local government, are grants but shared taxes, subsidies, and subventions are also common (Bird \& Smart, 2002).

Theory and empirical literature identify fiscal transfers with basically two characteristics. First, IGFTs are meant to facilitate national, regional, and local jurisdictions to achieve their various fiscal objectives. At national and regional levels, IGFTs are designed to help achieve efficient fiscal management, resource distribution equity, and macroeconomic stability. In local government, fiscal transfers' main purpose is to promote effective resource allocation and the attainment of quality service delivery (Cummings et al., 2009; Shah, 2006). Second, fiscal transfers are also intended to help sub-national entities come-up with a balanced revenue-expenditure structure. The well-adjusted and equilibrium structure is essential for effective fiscal planning and budget performance (Qian \& Weingast, 1996; Shah, 2006).

In practice, however, very few fiscal transfers can support the grantor-local entity's intended objectives effectively. Several factors have been attributed to the incapacitation, notable public finance and fiscal federalism scholars (e.g., Ali et al., 2013; de Mello, 1999; Ehrhart, 2012; Keen \& Mansour, 2010) place the responsibility on the transfers policy itself. Performance-orientation, bottom-up design, and clientfocus are the notable features of a typical inter-governmental fiscal transfers policy structure. The features dominate resource-strapped entities of the developing world (de Mello, 1999; Keen \& Mansour, 2010).

To date, no study is decisive enough on what precisely explains changes in intergovernmental fiscal transfers policy. However, recent empirical evidence in the works of Ali et al., 2013, Bird (2011), Cummings et al., 2009, Keen \& Mansour (2010), Moore (2004), and Prichard \& Leonard (2010) claim that it is local tax reforms that possibly predict transfers policy. Moreover, other scholars (e.g., Ehrhart, 2012; Morrissey, 2015) assert that fiscal transfers will never effectively impact national, regional, and local fiscal goals unless the governance forum's influence is acknowledged.

Guided by the coordination costs theory (Breton \& Scott, 1978) and the market preserving federalism theory (Qian \& Weingast, 1996), the current study investigates local tax reforms-intergovernmental fiscal transfers policy relationship, Sub-Saharan Africa. It also examines whether the governance forum mediates the local tax reformsinter-governmental fiscal transfers policy relationship.

Specifically, the research focuses on local government activities as conducted in Uganda, East Africa. The country's local entities are a focal point of investigation because Uganda stands out as a notable fiscal federalism player in Africa (de Mello, 1999; Moore, 2004; Shankar \& Shah, 2003). 


\section{Anticipated Study Contribution}

It is anticipated that this study will make several contributions to both intergovernmental fiscal transfers policy literature and theory. First, we contribute to the fiscal transfers policy literature by furnishing an explicit and systematic conceptual model. Such a framework build around robust theoretical underpinnings, the coordination costs theory (Breton \& Scott, 1978), and market preserving theory (Qian \& Weingast, 1996). It is perceived as capable of comprehensively explaining what that policy entails. Moreover, the framework is also very timely. It promptly responds to previous research (e.g., Bird \& Smart, 2002; de Mello, 1999; Shankar \& Shah, 2003)'s call for such innovative conceptualization in subsequent policy investigations.

Second, as remarked by (Cummings et al., 2009; Keen \& Mansour, 2010), past empirical results on what explains local fiscal transfers policy have been mostly mixedup and inconclusive. The conceptual model adopted in the current study provides a balanced view suitable for a rigorous test of related ideas and proposed hypotheses.

Thus, vigorous statistical tests such as multiple regression analysis (Aguinis \& Edwards, 2014), structural equation modeling (Bauer, 2003; Preacher et al., 2007), and bootstrapping analysis (Beran \& Srivastava, 1985) are employed to test paradoxical mechanisms surrounding the transfers policy.

\section{Theory, Literature, and Hypothesis Development}

\subsection{Intergovernmental Fiscal Transfers Policy}

It is estimated that intergovernmental fiscal transfers finance at least 70 percent of sub-national budgets in most Sub-Saharan African countries. Like elsewhere in the developing world, the transfers mainly comprise conditional, unconditional, and equalization grants (de Mello, 1999; Shankar \& Shah, 2003). Conditional or specificpurpose grants are meant to fund earmarked social infrastructure projects based on specific spending and accountability terms and conditions set by the central government.

Unconditional or general-purpose grants support local revenue collections in meeting recurrent expenditure and fostering day-to-day operational requirements (Bird \& Smart, 2002; de Mello, 1999). Equalization grants also referred to as fiscal horizontal transfers, are designed to create inter-entity fiscal equity to harmonize regional development equilibrium (Shah, 2006; Shankar \& Shah, 2003).

In sum, fiscal transfers policy should be designed and operated so that the grants engender incentive structures. This is regarding efficient fiscal management, quality public service provision, and accurate accountability (Bird \& Smart, 2002; de Mello, 1999; Shah, 2006; Shankar \& Shah, 2003). Theory, research, and practice identify such a policy-mechanism with three basic attributes: performance-orientation, bottom-up design, and client (community)-focus. 
Market-preserving federalism theory (Qian \& Weingast, 1996), one of the second generation fiscal federalism models, posits that inter-entity competition and hard budget constraints are critical sources of fiscal efficiency. When fiscal efficiency is attained, lower vertical fiscal imbalances and reduced fiscal transfers can be realized. This indicates high performance on the side of fiscal policy (de Mello, 1999; Qian \& Weingast, 1996).

Further, performing fiscal policy suggests an efficient governance structure. Such a system is capable of providing quality public goods and services and significantly preserves local market incentives (de Mello, 1999; Shankar \& Shah, 2003). Based on a strong rule of budgetary law (fiscal institutionalization), administrative power separation, and democracy, preserved market incentives stimulate an effective intergovernmental fiscal transfers policy (Shankar \& Shah, 2003).

However, attaining effective fiscal policies through preserved market incentives has been a big challenge, especially in Sub-Saharan African decentralized jurisdictions. For instance, in Uganda, the lack of an independent judicial system, partisan politics and tribalism, and questionable democracy fuel corruption and rent-seeking practices. These significantly undermine fiscal policy (Bird \& Smart, 2002; de Mello, 1999; Shankar \& Shah, 2003).

An effective intergovernmental fiscal transfers policy must specify the design of its individual transfers. Over the years, literature (e.g., Ali et al., 2013; Shah, 2006) and theory (Breton \& Scott, 1978; Qian \& Weingast, 1996) recommend a bottom-up design for both a regular transfers policy and individual transfers it governs. According to Ali et al. (2013), the bottom-up transfers policy design signifies that grantors are fully accountable to some administrative machinery and adhere to related budgetary regulations. Such an accountability framework is associated with service efficiencyequity and enriches entity fiscal health (Shah, 2006; Shankar \& Shah, 2003).

Both the coordination costs theory (Breton \& Scott, 1978) and market preserving theory (Qian \& Weingast, 1996) advocate for a bottom-up design for various transfers on numerous grounds. It promotes accountability, affordability, autonomy, predictability, simplicity, and transparency, amongst others (Breton \& Scott, 1978). In developing countries, particularly those of Sub-Saharan Africa like Ghana, Nigeria, and South Africa, the fiscal transfers bottom-up design has been ineffective due to lack of accountability and transparency (Ali et al., 2013; Shah, 2006).

Their respective transfer policies are regulated by politically-driven weak judicial systems, therefore, mostly simplistic and unpredictable. While Uganda's transfer policy is relatively strong, its bottom-up design has also been compromised by sectarian and tribal practices (de Mello, 1999; Shankar \& Shah, 2003).

The essence of fiscal decentralization is to devolve largely central governmentcontrolled revenue sources and expenditure functions to lower government tiers (Bird \& Smart, 2002; Cummings et al., 2009). This implies that the policy governing intergovernmental fiscal transfers, the bedrock of fiscal decentralization, must be 
client-focused (Cummings et al., 2009). In this respect, the dominant client, lower tiers of government, and specifically their local communities, are meant to receive related public goods and services in the right qualities and on a timely basis.

However, some empirical evidence (Morrissey, 2015; Prichard \& Leonard, 2010; Shankar \& Shah, 2003) indicates that most fiscal transfer policy structures promote greater complexity in grantor-client relationships. For instance, some policies are too technical for local clients to implement the proposed programs effectively.

With low technical capacity typical of majority local entities in developing countries, transfers-related requirements cannot be easily interpreted (Prichard \& Leonard, 2010; Shankar \& Shah, 2003). This explains why various scholars (e.g., Bird \& Smart, 2002; Breton \& Scott, 1978; de Mello, 1999; Morrissey, 2015) have argued that the western world-formulated transfers policies, when adopted wholesome in Africa, undermine the policy client-focus objective.

Moreover, due to associated coordination failures, beneficiary local governments and their communities rarely appreciate the implementation and accountability requirements of grant policies. From fiscal decentralization inception in the early 1990s, Ugandan-based local entities generally embraced the fiscal transfers policy's client-focus attribute.

However, with time, the technical capacity-coordination failure linkages have rendered the client-focus drive practically ineffective (Ali et al., 2013; Bird, 2011; Shah, 2006).

\subsection{Local Tax Reforms}

To date, intergovernmental fiscal transfers policy dynamics in both the developed and developing world remain too complicated and not easy to predict. However, theory, notably coordination costs theory (Breton \& Scott, 1978) and market preserving federalism theory (Qian \& Weingast, 1996), claim that transfers policy effectiveness partially resides in local tax reforms. This is feasible if the associated reforms can be appropriately tailored to taxpayer income-generating capacity and poverty realities (Breton \& Scott, 1978; Qian \& Weingast, 1996).

In tandem, research (e.g., Ali et al., 2013; Bird, 2011; Cummings et al., 2009; Keen \& Mansour, 2010; Moore, 2004; Prichard \& Leonard, 2010) asserts that especially in resource-constrained economies of Sub-Saharan Africa, a local tax and their reforms can substantially explain changes in the transfers policy. In broad terms, tax reforms mainly entail a substantial transformation of target tax bases and increases in tax revenue-gross domestic product ratio (Keen \& Mansour, 2010; Moore, 2004).

However, the standard position on local tax reforms achievement from theoretical, practice, and empirical contexts is that improving tax systems' performance is complicated. Moreover, since it is largely tax context in nature, it requires no direct and simple answers (Cummings et al., 2009; Prichard \& Leonard, 2010). 
For instance, local taxes in most African jurisdictions are so minimal (despite the large local community populations expected to pay tax) that fiscal transfers must finance all public goods and services. Thus, carefully-conceived related tax reforms are critical if any transfer policy has to work-out meaningfully. Such reforms have to be executed regarding key tax attributes like tax autonomy, coordination capacity, tax inconsistency, and corruption (Keen \& Mansour, 2010; Prichard \& Leonard, 2010).

\subsubsection{Tax Autonomy}

Either at the national or local entity level, enforceable legislation for taxation and by extension related tax reforms is a function of two main factors: legal powers capable of coercing taxpayers and political legitimacy that drive legal authority (Bird, 2011; Keen \& Mansour, 2010). At the local government level, the two factors require that the concerned taxation authorities be adequately autonomous. Tax autonomy does not only empower the authorities to set-up and manage tax bases and tax rates effectively but tremendously enhance tax reformation (Keen \& Mansour, 2010; Moore, 2004).

Property tax and local service tax are the most dominant types of local taxes administered by the local government in most developing countries, those of SubSaharan Africa inclusive. They also constitute the most significant local revenue source in such jurisdictions, although fees, licenses, and market dues are also collected. Thus, as noted by Cummings et al. (2009) and Prichard \& Leonard (2010), local authorities frequently undertake property tax and local service tax reforms to boost their local revenue collections.

Adequate local collections are critical in co-financing fiscal transfers as the latter are often unreliable both in amount and timing. This action is, however, effective only in an autonomous tax environment. Moreover, the transfer policy must also be equally realistic enough to accommodate the local taxation authorities (Ali et al., 2013; Keen \& Mansour, 2010).

In practice, attaining efficient tax autonomy-transfers policy collaboration is largely elusive. This is mainly due to several local tax reform drivers. First, tax reforms in countries such as Tanzania, Uganda, and Zambia, to name but a few decentralized African states, have often been formulated and imposed by the donor community, especially the IMF. The donors require that local authorities focus on increasing tax collection and taxpayer compliance rather than broadening tax bases.

Widening tax bases is considered complicated and time-consuming, especially amidst the available technical capacity limitations. Several scholars (e.g., Bird, 2011; de Mello, 1999; Ehrhart, 2012; Keen \& Mansour, 2010) regard donors' approach to local tax reform-transfers policy linkages as totally autocratic and responsible for frustrating local fiscal autonomy. 
Second, tax autonomy-transfers policy alliance in such countries is undermined by sectarian and partisan political practices. According to Prichard \& Leonard (2010), politics and weak governance mechanisms dominate taxation law in Uganda. Thus, local entity autonomy concerning required tax reforms cannot be realized simply because politically-driven elites rarely reverence the law.

The above tax autonomy-transfers policy analysis stimulates embracing the ensuing proposition:

Hypothesis 1: Tax autonomy has a positive relationship with fiscal transfers policy.

\subsubsection{Coordination Capacity}

As an essential local tax reform attribute, coordination between central and local levels enhances tax duplication avoidance. Besides, coordination capacity has also been identified with efficient management of inconsistencies that often emerge in the local authority-imposed taxes-national government development policies relationships (Cummings et al., 2009; Keen \& Mansour, 2010; Moore, 2004). In subnational entities of most fiscally-decentralized countries of Africa, tax duplication and management inconsistencies are very rampant. It is widely argued in related empirical work (e.g., Keen \& Mansour, 2010; Moore, 2004; Shankar \& Shah, 2003) that failure in majority fiscal transfers policies operated by these countries originate from tax duplication. Moreover, transfer policy is often ineffective because of failure in managing local taxes-national government development policy linkages.

Both practice and research (Ali et al., 2013; Bird, 2011; Bird \& Smart, 2002) acknowledge the reality that coordination capacity is quite a complex scenario in the management of local tax reforms. The complexity even generates policy conflicts between the central government and local authorities. For instance, Bird and Smart (2002) cite a related scenario in Uganda, where numerous local governments have been imposing a tax on some export crops. The practice is contrary and completely inconsistent with the national government policy of promoting export production (Bird, 2011; Bird \& Smart, 2002).

Based on the foregoing coordination capacity-intergovernmental fiscal transfers policy debate, the following hypothesis can also be proposed:

Hypothesis 2: Coordination capacity relates positively to fiscal transfers policy.

\subsubsection{Tax Inconsistency}

It is common practice that national tax authorities and local government tax jurisdictions operate different tax collection systems (Ali et al., 2013; Keen \& Mansour, 2010). According to public finance literature (e.g., Shah, 2006; Shankar \& Shah, 2003), the central government generates revenue to fund administrative, political, security, 
diplomacy, and international relations, and most importantly, micro and macroeconomic activities.

Like local governments' revenue, a subnational authority is primarily meant to finance entity administrative responsibilities and community-based development projects (Shah, 2006; Prichard \& Leonard, 2010). The resultant lack of unity does not only cripple efforts to infiltrate unexploited tax areas but often compromises fiscal transfer policy effectiveness. Transfers policy implementation is undermined further by divergences in legal mechanisms and rampant bureaucracy.

In Uganda, a Tax Register Expansion Project or TREP was recently introduced to handle Uganda Revenue Authority (URA)-local government tax systems inconsistencies (Ali et al., 2013; Bird, 2011). To date, TREP, which operates in Kampala city and other urban areas, seems to have achieved little and is frequently accused by rural-based local entities of sidelining them. The project is politically-motivated with little concern for public service delivery (Bird, 2011).

Moreover, the inconsistency reveals other URA-local entity operational evidence such as lack of partnership equity and payment of agency fees to local entities (Bird, 2011; Keen \& Mansour, 2010). Thus, it is proposed as follows:

Hypothesis 3: Tax inconsistency and intergovernmental fiscal transfers policy relate positively.

\subsubsection{Corruption}

Complicated and non-transparent local government tax systems are costly to administer and frustrating to local tax reform efforts and tremendously enhance corruption practices. Corruption, which is often exacerbated by bribery and sometimes money laundering, leads to tax evasion. The objective is to frustrate local tax collection and intended support to the central government's fiscal transfers policy (Keen \& Mansour, 2010; Prichard \& Leonard, 2010).

In most Sub-Saharan African fiscal federalism countries, including Uganda, corruption among local taxpayers is perpetuated by systematic networks, wage differentials, and weak internal control mechanisms (de Mello, 1999; Cummings et al., 2009; Morrissey, 2015; Shankar \& Shah, 2003). It is often manifested in two forms: direct extortion from taxpayers (abusive dimension) or collusively by condoning and benefiting from tax avoiders' corrupt behaviors.

Curbing corruption tendencies in local entities has not been an easy task. For instance, in most Ugandan-based local jurisdictions, revenue is stolen by the administrators themselves with impunity (Cummings et al., 2009; Shankar \& Shah, 2003). However, some scholars (e.g., de Mello, 1999; Morrissey, 2015) have for a long time emphasized transparency, an accountability extension, as a corruption-mitigating weapon, but it has also not been entirely effective. 
According to Morrissey (2015), transparency can be more impactful if taxpayers are regularly exposed to tax information and decision-making forums. This will make communities familiar with the way tax bases are actually determined and local tax rates set. Moreover, local authorities should enhance regular monitoring and supervision to ensure that all potential revenues are collected, recorded, and submitted (de Mello, 1999; Cummings et al., 2009; Morrissey, 2015). Against this background, the following hypothesis can be suggested:

Hypothesis 4: Corruption relates positively to intergovernmental fiscal transfers policy.

\section{Governance Forum}

Effective management of an intergovernmental fiscal transfers policy and executing productive local tax reforms center around the issue of governance (Ehrhart, 2012; Morrissey, 2015). Under fiscal federalism governance, almost all countries in both the developed and developing world often assign various expenditure functions to sub-national governments.

Unfortunately, the assignment is regularly much heavier than can practically be funded from those entities' revenue sources (Bird \& Smart, 2002; Morrissey, 2015). The resultant functions-financing mismatch, commonly referred to as vertical fiscal imbalances (de Mello, 1999; Qian \& Weingast, 1996), compels sub-national entities to rely on the central government for operational survival inevitably. The method globally employed in narrowing down this imbalance gap is extending fiscal transfers (grants) and mandating revenue sharing (local taxation) powers. This approach is typically a governance-forum manifestation (Qian \& Weingast, 1996; Shankar \& Shah, 2003).

Practice, theory (Breton \& Scott, 1978; Qian \& Weingast, 1996), and empirical evidence (e.g., Cummings et al., 2009; Keen \& Mansour, 2010; Moore, 2004), concur that when fiscal governance-forum is well administered, it empowers local tax reforms to enhance efficiency in fiscal transfers policy. However, the challenge is that most nations in technical capacity-scanty and resource-strained regions such as that of SubSaharan Africa either deliberately ignore that reality or are defeated to initiate the move.

Some scholars (Ali et al., 2013; Shah, 2006; Prichard \& Leonard, 2010) believe that it is a defeat that transpires in majority jurisdictions. This is clearly expressed as reliance on donor and international financial institutions' advice, which is sometimes misleading. In Uganda, for instance, doubts are cast on the prevailing transfers policy because of an inappropriate governance approach (Prichard \& Leonard, 2010). Moreover, local tax reforms are undertaken by most local entities that rarely achieve intended objectives because of partisan politics, tribalism, and a fiscal corruptiondriven approach to governance. The overriding mindset is that donor support is almost a certainty, and it must come (Ali et al., 2013; Shah, 2006). 
From the foregoing local tax reforms-transfers policy deliberations, we proposed the following:

Hypothesis 5: Governance forum mediates the local tax reforms-transfers policy relationship.

\section{Methods: Sample and Procedure}

In order to test the current study hypotheses on local tax reforms-governance forum-transfers policy triangulation, an operations survey was administered (Aguinis \& Edwards, 2014). The investigation focused on a number of districts, municipalities, and sub-counties located in the north-western region of Uganda, East Africa.

The target 8 districts, 2 municipalities, and 80 sub-counties (units of analysis), particularly those of the West Nile sub-region, were purposively selected given their historical transfers policy volatile performance record (Bird \& Smart, 2002; Shankar \& Shah, 2003).

The study sample size was 265 participants comprising 19\% administrators (chief administrative officers, resident district commissioners, town clerks, and local council 5 chairpersons), 15\% chief finance officers, $26 \%$ heads of department, 33\% finance operations-related employees, and 7\% community representatives. As recommended by previous and similar research (e.g., Aguinis \& Edwards, 2014; Bauer, 2003), a combination of both purposive and pure random sampling procedures was employed in constituting the study sample components.

Of the 265 instruments administered, 241 were returned, providing a total response rate of $91 \%$, much higher than the $65 \%$ mean rate recommended (Bauer, 2003; Preacher et al., 2007) for surveys of this kind. With no missing data recorded, the study found that $58 \%$ of the participants were male and $42 \%$ female. Their mean age was 37 years ( $S D=1.742)$, and the mean job tenure period was 7 years ( $S D=1.384)$. Besides, statistics also indicated that while $61 \%$ of the respondents were married, $37 \%$ were single, and the rest divorce. Finally, $15 \%$ of these respondents are certificate holders, $26 \%$ hold diplomas, and 59\% are bachelor's degree-and-above holders.

\section{Measures}

Measurement of the various study constructs indicated in the following sections was based on an item-response scale ranging from 1 (Strongly Disagree) to 5 (Strongly Agree). This scale-range dominates recent research (e.g., Bird \& Smart, 2002; Ehrhart, 2012; Moore, 2004; Shah, 2006). Accordingly, the following variable constructs were measured as follows:

- Performance orientation was measured using a 12-item scale developed by Bird and Smart (2002) with an internal consistency coefficient alpha ( $\alpha=0.89)$. 
Sample items include: "Fiscal transfers policy performance is regarded seriously in this local government"; "The entity often complies with policy requirements".

- To measure the Bottom-up Design construct, we modified and employed a 10item scale $(\alpha=0.91)$ adopted by Shah (2006). Sample item: "The transfers policy bottom-up approach is not practical in reality."

- We measured the client-focus attribute of transfers policy by means of a 13item scale developed by de Mello (1999) and Shankar and Shah (2003). Sample items with $(\alpha=0.87)$ included the following: "Clients are critical for fiscal transfers policy implementation effectiveness"; "Clients rarely participate in transfers policy implementation".

- Based on 13-items $(\alpha=0.94)$ closely related to those in the scales employed by Ali et al. (2013) and Cummings et al. (2009), the status of tax autonomy in surveyed local governments was evaluated. One of the items was: "This local entity has never been autonomous in tax management."

- A total of 11 items designed along the lines of those in the work of Moore (2004) was engaged to measure coordination capacity. The item's reliability coefficient was $(\alpha=0.90)$. Sample item: "[...] coordinates its tax activities systematically".

- We modified scales used by Bird (2011) and Prichard and Leonard (2010) to the 12 closely-related items in order to measure tax inconsistency. With a collective $(\alpha=0.85)$, one of such items read as follows: "Any inconsistency that arises in this entity's tax reform agenda is always addressed immediately".

- The construct corruption was assessed by 12 items $(\alpha=0.93)$ in a scale originally designed by Keen and Mansour (2010) but tailored to this research. A typical item in the scale was: "Corruption practices never influence local tax reforms in this entity".

- Measurement scales formulated by both Ehrhart (2012) and Morrissey (2015) were replicated to support the 14 items that evaluated the governance forum variable. The items' reliability was $(\alpha=0.91)$, and one of them ran as follows: "Governance is critical for effective implementation of transfers policy".

\section{Control Variables}

Participant key biographical attributes: gender, age structure, marital status, educational level, a position occupied, and period served in respective local entities, were controlled. Similar studies (e.g., de Mello, 1999; Keen \& Mansour, 2010; Morrissey, 2015; Shankar \& Shah, 2003) emphasize that naturally, biographical 
variables tend to impair dependent variable evaluations. Thus they must be controlled if realistic results have to be generated (de Mello, 1999; Morrissey, 2015).

Accordingly, the factors were controlled for as follows: [Gender: ( $0=$ female, $n=87 ; 1=$ male, $n=154)$ ]; [Age in years: $(1=20-30, n=29 ; 2=31-40, n=136 ; 3=41+, n=76)$ ]; [Marital status: ( $1=$ single, $n=48 ; 2=$ married, $n=143 ; 3=$ others $n=50)$ ]; [Educational level: (1=certificate, $n=17 ; 2=$ diploma, $n=71 ; 3=$ bachelor's degree,$+ n=153)$ ]; [Job tenure in years: $(1=1-3, n=61 ; 2=4-6, n=139 ; 3=7+, n=41)]$.

In order to assess instrument validity effectively, simulation research (e.g., Aguinis \& Edwards, 2014; Beran \& Srivastava, 1985) recommends engagement of at least one hypothetical and latent variable. Its validity status is then verified by employing Harman's One Factor confirmatory factor analysis. However, given the factor's potential influence on hypotheses test results (Beran \& Srivastava, 1985), we also controlled for it.

\section{Data Analysis}

Before carrying out full-scale data analysis, the study instrument's internal consistency (reliability) and validity were first established (Aguinis \& Edwards, 2014). Using the SPSS package, the study variable-construct inferential statistics were then generated to highlight their means, standard deviations, and correlation status (Beran \& Srivastava, 1985).

Study hypotheses' direct and mediation effects were tested using hierarchical regression analysis (Bauer, 2003; Beran \& Srivastava, 1985) and the AMOS softwarebased structural equation modeling (SEM) technique. The SEM approach was adopted based on the conventional double-step strategy (Preacher et al., 2007). First, it verifies required consistency between espoused hypothetical models and original data, and secondly, establishes the hypotheses direct-mediation effects (Bauer, 2003; Preacher et al., 2007).

\section{Results}

\subsection{Descriptive and Correlation Statistics}

Table 1 presents the means, standard deviations, reliability coefficients, and the zero-order correlations of the study variables and constructs. As suggested in previous research (Aguinis \& Edwards, 2014; Bauer, 2003; Beran \& Srivastava, 1985), all intercorrelations were first corrected for attenuation using reliability estimates. 
Table 1: Variable Means, Standard Deviations, Reliability Coefficients, and Correlations

\begin{tabular}{|c|c|c|c|c|c|c|c|c|c|c|c|c|c|}
\hline \# & Variable & $M$ & $S D$ & 1 & 2 & 3 & 4 & 5 & 6 & 7 & 8 & 9 & 10 \\
\hline 1 & Tax Autonomy & $\begin{array}{l}3 . \\
15\end{array}$ & 1.54 & .87 & & & & & & & & & \\
\hline 2 & $\begin{array}{l}\text { Coordination } \\
\text { Capacity }\end{array}$ & $\begin{array}{l}3 . \\
02\end{array}$ & 1.59 & $.27^{* *}$ & .91 & & & & & & & & \\
\hline 3 & $\begin{array}{c}\text { Tax } \\
\text { Inconsistency }\end{array}$ & $\begin{array}{l}3 . \\
08\end{array}$ & 1.53 & .342 & $.29^{*}$ & .93 & & & & & & & \\
\hline 4 & Corruption & $\begin{array}{l}3 . \\
00\end{array}$ & 1.54 & $.19^{* *}$ & -08 & $.29^{*+}$ & .82 & & & & & & \\
\hline 5 & $\begin{array}{l}\text { Local Tax } \\
\text { Reforms }\end{array}$ & $\begin{array}{l}2 . \\
90\end{array}$ & 1.60 & $.15^{\star}$ & .26 & -.42 & $.57^{* *}$ & .85 & & & & & \\
\hline 6 & $\begin{array}{l}\text { Governance } \\
\text { Forum }\end{array}$ & $\begin{array}{l}3 . \\
05\end{array}$ & 1.58 & -.28 & $.14^{* *}$ & .28 & $.17^{* *+}$ & $-.42^{* *}$ & .92 & & & & \\
\hline 7 & $\begin{array}{l}\text { Perfmance } \\
\text { Orientation }\end{array}$ & $\begin{array}{l}2 . \\
93\end{array}$ & 1.55 & -.35 & .24 & $.36^{*+}$ & -.38 & -.18 & $-.35^{*}$ & .88 & & & \\
\hline 8 & $\begin{array}{l}\text { Bottom-up } \\
\text { Design }\end{array}$ & $\begin{array}{l}3 . \\
06\end{array}$ & 1.57 & .23 & $-.10^{*}$ & .34 & $.14^{*}$ & -.26 & .22 & $-.28^{* *}$ & .94 & & \\
\hline 9 & Client Focus & $\begin{array}{l}3 . \\
06\end{array}$ & 1.57 & $.42^{* *}$ & -.31 & $.20^{*}$ & -.44 & $-.19^{* *}$ & .33 & $-17^{*}$ & $-.37^{* *}$ & .84 & \\
\hline 10 & IGFTs Policy & $\begin{array}{l}2 . \\
99\end{array}$ & 1.56 & -.12 & $.34^{* *}$ & .28 & $-.34^{* *}$ & $.41^{*}$ & $-.51^{* *}$ & .27 & -.16 & $.32^{*}$ & .86 \\
\hline
\end{tabular}

Notes: Perfmance Orientation $=$ Performance Orientation; IGFTs = Inter-Governmental Fiscal Transfers; Reliability coefficients are in parentheses; ${ }^{*} \mathrm{p}<.01$ two-tailed test; ${ }^{* *} \mathrm{p}<.05$ two tailed-test; $\mathrm{n}=$ 241.

The tabulated results indicate that overall, various inter-correlations were statistically significant. Practically, this suggests that there was clear inter-variable distinctions and relationships (Bauer, 2003; Beran \& Srivastava, 1985).

For instance, government forum negatively but significantly relates to local tax reforms to the extent of $(r=-.42, p<.01)$. This implies that tax reforms' improvement to a magnitude of $42 \%$ leads to slackening in government forum activities to the same level.

Moreover, intergovernmental fiscal transfers policy displays a significant and positive relationship with tax reforms of $(r=.41, p<.05)$ but relates negatively (albeit significantly) with governance forum to an extent of $(r=-.51, p<.01)$.

\subsection{Hypothesis Testing}

Both hierarchical regression analysis and structural equation modeling used in testing the study hypotheses were conducted after first centering its variables (Beran \& Srivastava, 1985). Centering, meant to minimize data multi-collinearity threat, is executed by subtracting each variable mean from each individual score (Beran \& Srivastava, 1985; Preacher et al., 2007). 
Additionally, variable tolerance values (TV) and variance inflation factors (VIF) for all independent and control variables were computed to assess the multicollinearity further. As an empirical rule of thumb (Bauer, 2003; Preacher et al., 2007), $(\mathrm{TV}<1.0)$ and (VIF < 10.0) signify the absence of multi-collinearity threat to the dataset. Data on both TV and VIF presented in Table 2 indicate conformity to this empirical requirement.

Table 2: Multiple Regression Coefficients and Structural Equation Modeling

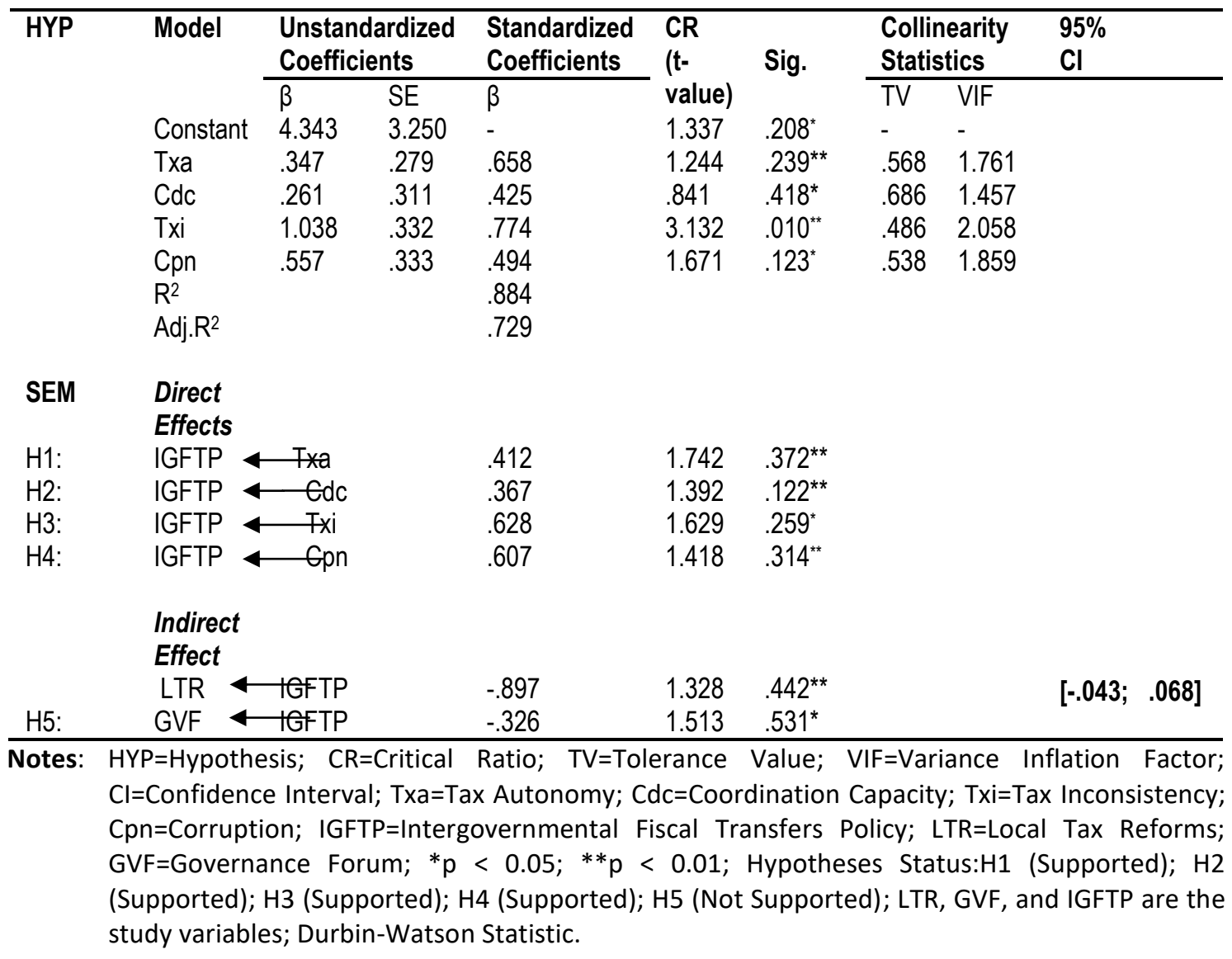

Under structural equation modeling, we adopted basically three models: a measurement model, a structural model, and Harman's Single Factor model as recommended by Beran and Srivastava (1985). The measurement model is meant to assess latent variables-manifest variables relationships. In contrast, the structural model constitutes the foundational model required for testing group invariances under the AMOS maximum likelihood procedures.

Harman's One Factor model is designed to assess the common methods variance threat rampant in social sciences-based surveys (Bauer, 2003; Beran \& Srivastava, 1985). Results from confirmatory factor analysis (CFA) executed on the six latent factor-based measurement model employed, exhibited quite significant item 
loadings. Its goodness-of-fit indices $(\chi 2=16.438 ; \mathrm{df}=7 ; \chi 2 / \mathrm{df}=2.348 ; \mathrm{IFI}=0.977 ; \mathrm{TLI}=$ 0.995; CFI = 0.991; RMSEA = 0.078; L.411, H.926) were also relatively strong. Bauer (2003) associates such results with potential structural equation modeling dependability.

Moreover, CFA was also executed on the Harman's model. Its goodness-of-fit indices $(X 2=10.726 ; \mathrm{df}=11 ; \chi 2 / \mathrm{df}=0.975 ; \mathrm{IFI}=0.805 ; \mathrm{TLI}=0.723 ; \mathrm{CFI}=0.894 ; \mathrm{RMSEA}$ $=0.216$; L.005, H.178) relative to those of the measurement model counterpart were very weak. The low-profile Harman's model CFA results are indicative of no common methods variance threat to the dataset (Bauer, 2003; Preacher et al., 2007).

The generally robust reliability coefficients $(\alpha \geq .85)$ (Table 1$)$, largely significant factor loadings $(\beta>0.35, p<0.01 ; p<.01)$ (Table 2$)$, and absence of the common methods variance threat collectively suggest strong construct and discriminate validity of the instrument used in the current study (Preacher et al., 2007). Structural models with high goodness-of-fit indices are often recommended for testing hypotheses' direct and indirect effects meaningfully. Thus, as underscored in the work of Beran and Srivastava (1985), we engaged the model with the following indices profile: $(\chi 2)=1.751$; $\mathrm{df}=1 ; \mathrm{p}=.425 ;(\chi 2 / \mathrm{df})=1.751 ; \mathrm{GFI}=.991 ; \mathrm{NFI}=.983 ; \mathrm{RFI}=.952 ; \mathrm{IFI}=.987 ; \mathrm{TLI}=.966 ; \mathrm{CFI}=.972 ;$ RMSEA $=.027(L .000 ; H .174)$ at 90 , in order to analyze the required effects.

\subsubsection{Direct Effect Tests}

Hypothesis 1 predicted that tax autonomy would positively predict changes in intergovernmental fiscal transfers policy. In support of this hypothesis, both the regression analysis $(\beta=.658, p<0.01$, t-value 1.244) and SEM $(\beta=.412, p<0.01, t$-value 1.742) results (Table 2 ) indicate that indeed the path from tax autonomy to intergovernmental fiscal transfers policy is significant and positive. In Hypothesis 2, it was proposed that coordination capacity relates positively to the fiscal transfers policy. The regression results $(\beta=.425, p<0.05$, t-value .841$)$ and SEM $(\beta=.367, p<0.01$, tvalue 1.392) also confirm that positive and significant path.

Additionally, Hypotheses 3 and 4 projected positive and significant relationships between tax inconsistency and corruption and fiscal transfers policy respectively. Tax inconsistency-fiscal transfers policy regression analysis $(\beta=.774, p<0.01$, t-value 3.132) and SEM $(\beta=.628, p<0.05, t$-value 1.629) results and those of corruption-fiscal transfers policy $(\beta=.494, p<0.05$, t-value 1.671) and SEM $(\beta=.607, p<0.01$, t-value 1.418) approve those predictions.

In sum, consistent with reliable model goodness-of-fit statistics: $[(\chi 2 \mathrm{df})=0.292$; $\mathrm{df}=1 ; \mathrm{p}=0.589 ; \quad(\mathrm{X} / \mathrm{df})=0.292 ; \mathrm{GFI}=.975 ; \mathrm{NFI}=.997 ; \mathrm{RFI}=.954 ; \quad \mathrm{IFI}=1.007 ; \quad \mathrm{TLI}=1.131 ;$ CFI=1.000; RMSEA=.037 (L.000; H.139) at 90] (Preacher et al., 2007), all the hypotheses proposed for direct effect analysis secured support from the data. 


\subsubsection{Indirect (Mediation) Effect Test}

In order to establish whether governance forum mediates the local tax reformsintergovernmental fiscal transfers policy relationship in local government as predicted in Hypothesis 4, a suitable model was adopted. As suggested by past mediation research (Beran \& Srivastava, 1985; Preacher et al., 2007), the model's goodness-of-fit indices: $[(\chi 2 \mathrm{df})=0.044 ; \mathrm{df}=1 ; \mathrm{p}=.834 ;(\chi 2 / \mathrm{df})=0.044 ; \mathrm{GFI}=.977 ; \mathrm{NFI}=.999 ; \mathrm{RFI}=.997$; $\mid \mathrm{FI}=1.021 ; \mathrm{TLI}=1.066 ; \mathrm{CFI}=.986 ; \mathrm{RMSEA}=.041$ (L.015; H.101) at 90], were fairly strong and exhibit required statistical significance.

The preliminary mediation results: $[(\beta=-0.897, p<0.01$, t-value $1.328 ; \beta=-$ $0.326, p<0.05$, t-value 1.513)], displayed in Table 2, suggest that data did not support Hypothesis 4. Contrary to practice, theoretical (Breton \& Scott, 1978; Qian \& Weingast, 1996), and empirical (Ehrhart, 2012; Morrissey, 2015) expectations, the results imply that governance forum is not relevant for local tax reforms to impact changes in intergovernmental fiscal transfers policy in local entities.

In order to address this contradiction, Preacher et al., 2007 advise that mediation data be subjected to further statistical verification to confirm the preliminary findings. Thus, the conventional bootstrapping approach (Bauer, 2003; Preacher et al., 2007) based on 2,000 replicated sub-samples was employed. As shown in Table 2, the sub-samples displayed a statistically-insignificant governance forum effect-size comprising a 95\% bias-corrected confidence interval $(\mathrm{Cl})$ of: $[-0.043 ; 0.068]$.

The bias-corrected ( $\mathrm{Cl})$ : $[-0.043 ; 0.068]$ range is considered statisticallyinsignificant because it does not only hold a zero-value within it but, most importantly, indicates no governance forum mediation in the local tax reforms-transfers policy relationship (Bauer, 2003; Beran \& Srivastava, 1985). This position further suggests that the preliminary mediation test results are confirmed, and that data also support both results.

\section{Discussion}

This study was motivated by a desire to properly understand the relationship between local tax reforms and intergovernmental fiscal transfers policy in local government as often highlighted in earlier theoretical and empirical models (Breton \& Scott, 1978; de Mello, 1999; Keen \& Mansour, 2010). It was also critical to focus on the governance forum since previous research (Ehrhart, 2012; Morrissey, 2015) regularly cited it as a possible mediator in the local tax reforms-transfers policy relationship.

Its results showed that each of the local tax reforms attributes: tax autonomy, coordination capacity, tax inconsistency, and corruption, were significantly related to the transfers policy. However, the governance forum does not mediate the local tax reforms-transfers policy linkages. In the following sections, we discuss the study 
findings' theoretical and practical implications and their limitations and propose a possible future research direction.

\section{Theoretical Implications}

Both the coordination costs theory (Breton \& Scott, 1978) and market preserving federalism theory (Qian \& Weingast, 1996) and research (e.g., Cummings et al., 2009; Prichard \& Leonard, 2010) assert that a significant portion of fiscal transfers policy activities is directly attributed to local tax reforms. Much as the link had not been empirically verified conclusively, this study's findings support that proposition.

Thus, its first contribution to both theory and literature is that the transfers policy, specifically that operated in the Ugandan-based local entities, is apparently founded on a suitable theoretical structure. This tax reforms-transfers policy theoretical grounding is likely to engender positive policy implementation results if appropriately managed (Bird \& Smart, 2002; Shankar \& Shah, 2003). As shown earlier by Moore (2004), if, for instance, adequate tax autonomy is granted and tax inconsistencies regularly addressed, transfers policy goals can be easily realized.

The second contribution is that the current study finds no mediation influence of governance forum on local tax reforms-transfers policy association. This evidence is in line with Shankar \& Shah (2003) view that the involvement of governance concerns in fiscal policy sometimes inhibits effective policy implementation. This is rampant in developing countries, particularly those of Sub-Saharan Africa, whose governance capacity is typically weak and often derailed by pre-mature partisan politics (Shah, 2006; Shankar \& Shah, 2003). Thus, much as the theoretical foundation may be appropriate, governance contribution to transfers policy efficiency may be compromised. In Uganda, according to Shah (2006), even tribalism seriously undermines policy goals.

\section{Practical Implications}

This research holds important practical implications for administrators, employees, and councilors, and their local entities. Its findings show that it is extremely beneficial for them to manage local tax reforms effectively if the transfers policy has to operate meaningfully. This is particularly important given that local taxes are meant to substantially support central government fiscal transfers in order to achieve both micro and macroeconomic objectives. According to Ali et al. (2013) and Cummings et al. (2009), local tax supplement to fiscal transfers is not merely a requirement but a fiscal performance necessity in most developing nations. Notably, it helps address horizontal fiscal imbalances typical of such countries.

Moreover, as noted by Bird (2011) and Moore (2004), local entities must also endeavor to fully-appreciate the workings of a regular transfers policy. That knowledge 
will align anticipated tax reform measures to policy requirements and tailor potential outcomes to local fiscal realities. From this particular context, some scholars (e.g., Ehrhart, 2012; Morrissey, 2015) argue that it becomes meaningless for local jurisdictions to acquire tax reform-transfers policy understandability if the governance forum is sidelined.

\section{Limitations and Future Research}

A cross-sectional research design (Aguinis \& Edwards, 2014) was primarily employed in carrying out this study. Thus the causality interpretations thereof were only based on co-variance evidence and one's appreciation of proposed theoreticalconceptual linkages. Besides, the attempt to address the challenge by merely conducting confirmatory factor analysis for construct validity verifications and generating data from multiple sources (Aguinis \& Edwards, 2014; Prichard \& Leonard, 2010) could also not deter the design's setbacks. Accordingly, we propose that future studies adopt a longitudinal method with preferably a mixed-methods approach.

The study provides new insights into how local tax reforms are related to the local government's fiscal transfer policy. However, it does not address how effectively the reforms can be triggered and managed sustainably to generate realistic transfer policy changes. Hence, it would be useful to conduct in-depth research to understand better how tax reforms can be initiated and the transfer policy impacted accordingly.

Finally, evidenced by rampant conflicts in past empirical results (Keen \& Mansour, 2010, Prichard \& Leonard, 2010; Shankar \& Shah, 2003), ambiguity has often surrounded fiscal transfers policy theoretical-conceptual framework. Results of the present research were no exception to that problem. Thus, we encourage future studies to be more vigilant when developing theoretical-conceptual models to come up with actual results.

\section{Conclusion}

Local tax reforms and intergovernmental fiscal transfers policy have taken center stage in recent fiscal federalism literature. Very little is clearly understood as to what exactly defines a reliable transfers policy, especially in resource-strained economies of Sub-Saharan Africa. Drawing upon both coordination costs theory (Breton \& Scott, 1978) and market preserving federalism theory (Qian \& Weingast, 1996), this research found tax autonomy, coordination capacity, tax inconsistency, and corruption positively predict changes in the transfers policy. Conversely, governance forum (an acclaimed factor in previous studies) plays a very minor role in the local tax reforms-transfers policy relationship. Accordingly, the preceding findings may not have impacted the theory-research-practice triangulation alone, but they significantly broadened the intergovernmental fiscal transfers policy knowledge body. 


\section{References}

Aguinis, H. \& Edwards, J. R. (2014). "Methodological wishes for the next decade and how to make wishes come true", Journal of Management Studies, 51, 143-174.

Ali, M., Fjeldstad, O-H. \& Sjursen, I. (2013). "To pay or not to pay? Citizens'attitude towards taxation in Kenya, Tanzania, Uganda and South Africa", World Development, 64, 828-842.

Bauer, D. J. (2003). "Estimating multilevel linear models as structural equation models", Journal of Educational and Behavioral Statistics, 28(2), 135-167.

Beran, R., \& Srivastava, M. S. (1985). "Bootstrap tests and confidence regions for functions of a covariance matrix", Annals of Statistics, 13, 95-115.

Bird, R.M. (2011). "Sub-national taxation in developing countries: A review of the literature", Journal of International Commerce, Economics and Policy, 2(1), 139161.

Bird, R. \& Smart, M. (2002). "Intergovernmental fiscal transfers: International lessons from developing countries", World Development, 30(6), 899-912.

Breton, A. \& Scott, A. (1978). The economic constitution of federal states, Toronto University Press, Toronto, Canada.

Cummings, R. G., Martinez-Vazquez, J., Mckee, M. \& Togler, B. (2009). "Tax morale affects tax compliance: Evidence from surveys and art factual field experiments", Journal of Economic Behavior and Organization, 70, 447-468.

De Mello, Jn. L. R. (1999). "Intergovernmental fiscal relations: Coordination, failures and fiscal outcomes", Public Budgeting and Finance, 19(1), 3-25.

Ehrhart, H. (2012). "Assessing the relationship between democracy and domestic taxes in developing countries", Economics Bulletin, 32, 551-572.

Keen, M. \& Mansour, M. (2010). "Revenue mobilization in Sub-Saharan Africa: Challenges from international trade reforms", Development Policy Review, 28, 553- 571.

Moore, M. (2004). "Revenues, state formation, and the quality of governance in developing countries", International Political Science Review, 25, 297-315.

Morrissey, O. (2015). "Aid and domestic resource mobilization with a focus on SubSaharan Africa", Oxford Review of Economic Policy, 31(3-4), 447-461.

Preacher, K. J., Rucker, D. D. \& Hayes, A. F. (2007). "Addressing moderated mediation hypotheses: Theory, methods, and prescriptions", Multivariate Behavioral Research, 42, 185-227.

Prichard, W. \& Leonard, D. (2010). "Does reliance on income taxes build state capacity in Africa?", International Review of Administrative Sciences, 67(4), 653-675. 
Qian, Y. \& Weingast, B. (1996). "China's transition to markets: Market-preserving federalism, the Chinese Style", Journal of Policy Reform, 1(2), 149-186.

Shah, A. (2006). "A practitioner's guide to intergovernmental fiscal transfers", Revista de Economia Estadistica, Cuarta Epoca, 44(2), 127-186.

Shankar, R. \& Shah, A. (2003). "Bridging the economic divide within countries: A scorecard on the performance of regional policies in reducing regional income disparities", World Development, 31(8), 1421-1441. 